\title{
Evaluation of Factors to Respond to the COVID-19 Pandemic Using DEMATEL and Fuzzy Rule-Based Techniques
}

\author{
Shahla Asadi ${ }^{1} \cdot$ Mehrbakhsh Nilashi $^{2,8} \cdot$ Rabab Ali Abumalloh $^{3} \cdot$ Sarminah Samad $^{4}$. \\ Ali Ahani ${ }^{5} \cdot$ Fahad Ghabban $^{6} \cdot$ Salma Yasmin Mohd Yusuf $^{7} \cdot$ Eko Supriyanto $^{2}$
}

Received: 25 November 2020/Revised: 13 May 2021/Accepted: 17 May 2021/Published online: 24 June 2021

(C) Taiwan Fuzzy Systems Association 2021

\begin{abstract}
Since social and environmental conditions have changed dramatically in recent years, the spectrum of diseases caused by infections is also evolving rapidly. The outspread of COVID-19 has resulted in an emergency situation across the globe with significant effects on the population's lives, families, and societies, leading to concerns the World Health Organization. Accordingly, the virus has substantially threatened the Malaysians' public health and contributed considerably to increased healthcare expenses. Since the novel coronavirus was found in China,
\end{abstract}

Mehrbakhsh Nilashi

nilashidotnet@hotmail.com

1 Centre of Software Technology and Management, Faculty of Information Science and Technology, Universiti Kebangsaan Malaysia, 43600 Bangi, Selangor, Malaysia

2 School of Biomedical Engineering and Health Sciences, Faculty of Engineering, Universiti Teknologi Malaysia, Johor 81310 Skudai, Malaysia

3 Computer Department, Community College, Imam Abdulrahman Bin Faisal University,

P.O. Box. 1982, Dammam, Saudi Arabia

4 Department of Business Administration, College of Business and Administration, Princess Nourah bint Abdulrahman University, Riyadh, Saudi Arabia

5 Department of Business Strategy and Innovation, Griffith Business School, Griffith University, Brisbane, Australia

6 Faculty of Computer Science and Engineering, Information System Department, Taibah University, Madinah 41411, Saudi Arabia

7 Primary Care Medicine Department, Faculty of Medicine, Universiti Teknologi MARA, Sungai Buloh, 47000 Selangor, Malaysia

8 Centre for Global Sustainability Studies (CGSS), Universiti Sains Malaysia, 11800 George Town, Malaysia
Malaysia's government has started its actions according to the World Health Organization procedures and concentrated on addressing and preventing the spread of the infection. The present paper aims to find and evaluate the factors to respond to the COVID-19 outbreak in Malaysia, limiting the outspread of the disease in this country. This study used the Decision-Making Trial and Evaluation Laboratory (DEMATEL) and Fuzzy Rule-Based techniques to evaluate the factors through a set of questionnaires completed by the health care professionals. According to the data analysis results, movement control order, international travel restrictions, and the mass gathering cancellations were of most importance in the prevention of COVID-19 infections transmission.

Keywords Multi-criteria decision making - COVID-19 . Malaysian government · Public health - DEMATEL . Fuzzy rule-based

\section{Introduction}

The outspread of the COVID-19 virus, which caused respiratory problems, was initially emerged on the 31st of December, 2019 in Wuhan, Hubei province of China [1-3]. The virus spread across this country and then worldwide quickly. Several transmission cases by tourists were reported in different countries such as Taiwan, Singapore, Vietnam, Korea, Malaysia, Thailand, Japan, Germany, France, United States, and Australia, leading to serious health emergencies across the world [4]. All the activities were postponed globally due to the virus's outspread, it is supposed that the public health burden of COVID-19 would be increased, and therefore immediate decisions have to be made $[5,6]$. 
In Malaysia, the first case of COVID-19 was detected on 25 January 2020 and traced back to three Chinese citizens who previously had close contact with an infected person in Singapore [7, 8]. The number of infected persons remained less than 25 till the 1st of March [9]. After that, total COVID-19 cases enlarged gradually, leading to a sharp growth beginning on 14 March. The initial two mortality cases caused by COVID-19 were recorded on 17 March [10]. Following that, the number of death cases increased dramatically, however, the number remained less than 100 till 29 April. Since 30 April, the death rate because of COVID-19 was $1.70 \%$, below the worldwide average of $7.1 \%$ [9]. The government forced a two-week Movement Control Order (MCO) beginning from the $18^{\text {th }}$ of March to 31 March to decrease community spread and overburdening of the health system [11]. Based on MCO, the number of active cases of COVID-19 reduced gradually and was consistent as infected persons healed from COVID-19. Following the accelerated growth in the third wave's active cases, the Malaysian government organized a Conditional Movement Control Order (CMCO) beginning from 14 October 2020, at which 5768 active cases were recorded [12]. Until 8 November, the total number of cases was 40,209, and the daily number of infected individuals had increased surprisingly [12]. After recognizing the COVID-19 cases, the Prime Minister declared the implementation of the CMCO for Selangor's state based on preventive and proactive efforts.

Several studies have been conducted in terms of COVID-19 disease in the Malaysian context. Mat et al. [7] conducted a study focusing on the massive transmission of COVID-19 infections in Malaysia. They suggested that mass gatherings for religious or other determinations should be canceled and prevented during the COVID-19 pandemic. Another study by Nadzir et al. [13] showed how the estimated pollutants' level decreased to $60 \%$ by implementing MCO during the COVID-19 outbreak. Azlan et al. [11] examined the knowledge levels, attitudes, and practices of COVID-19 among Malaysian people. The results of their research showed that the most outstanding respondents $(83.1 \%)$ had positive attitudes to the effective control of COVID-19, the capability of Malaysia to overcome the disease was $95.9 \%$, and the way the Malaysian government controlling the crisis was $89.9 \%$. Sundarasen et al. [14] investigated COVID-19 and quarantine's psychological influence among university students in Malaysia. They found that from the 983 participants, $20.4 \%$, $6.6 \%$, and $2.8 \%$ encountered the smallest to medium, marked to critical, and most severe anxiety levels, respectively. Chung et al. [15], investigated university students' readiness for online learning during the COVID19 pandemic. They observed that, in general, the participants are slight to moderately willing to practice online learning. Many of them were not keen on online learning practice due to the absence of student control, self-directed education, and online communication productiveness.

Previous studies have neglected the importance of factors that influence COVID-19 prevention.

Kou et al. [16] highlighted that employing combined Multi-Criteria Decision Making (MCDM) methods to examine the decision problems is significant as the outcomes determined by the several MCDM methods are more reliable than solely relying on one MCDM technique. The Decision-Making Trial and Evaluation Laboratory (DEMATEL) approach has been effectively implemented in multiple disciplines by inspecting complicated political, economic, and scientific issues [17-20]. DEMATEL is particularly useful and beneficial for examining the complex causal relationships using particular measures. The measures depict a contextual relationship among the system's components, in which a number reflects the strength of the effect. Thus, the DEMATEL approach can transform the relationship among the cause and effect of measure into a comprehensible structural framework. MCDM concentrates on effectively ranking choices and reaching the best among various alternatives depending on several measures, which can help decision-makers make decisions accurately [21].

The present study investigates how Malaysia's government deals with the virus and its contribution to the mitigation of the risks associated with the virus. We rely on DEMATEL and Fuzzy Rule-Based techniques to evaluate the factors impacting the prevention of the rapid outspread of the COVID-19 virus. Firstly, the DEMATEL technique was employed to investigate the crucial factors for preventing COVID-19. After that, Fuzzy Rule-Based techniques were used to expose the significance level of determining factors based on the model inputs. This paper is organized as follows. In Sect. 2, the factors impacting the prevention of the rapid outspread of the COVID-19 virus are discussed. In Sect. 3, the methodology is presented. Data analysis results for the DEMATEL and Fuzzy Rule-Based approaches are provided in Sect. 4. In Sect. 5, the discussions on the results are provided. In Sect. 6, the conclusion and recommendations for future studies are presented.

\section{Factors to Respond to the COVID-19 Pandemic}

This study selected the frequently used factors in the previous research to respond to the COVID-19 pandemic in the Malaysian context. This is the first attempt by researchers to examine the factors that prevent the rapid outspread of the COVID-19 virus. As shown in Table 1, these factors comprise social media sharing, governmental 
Table 1 Identified factors in terms of COVID-19 from prior research

\begin{tabular}{|c|c|}
\hline Factors & References \\
\hline $\begin{array}{l}\text { Cancelation of Mass } \\
\text { Gathering }\end{array}$ & $\begin{array}{l}\text { Karami [22], Tee [23], Crawford et al. [24], Montanez [25], Ahmad et al. [26], Idris [27], Ahmed et al. [28], Escher } \\
\text { Jr [29], Alshammari et al. [30] }\end{array}$ \\
\hline Movement Control Order & $\begin{array}{l}\text { PMO [31], Aitsi-Selmi et al. [32], Sarif, Yahya [33], Yusof [34], Heikal Ismail et al. [35], Abdullah et al. [36], } \\
\text { Karim et al. [37], Khor et al. [38], Tang [39], Nadzir et al. [13], Ash'aari et al. [40] }\end{array}$ \\
\hline Social Media Sharing & Cinelli et al. [41], Ahani, Nilashi [42], Chinazzi et al. [43], Cuello-Garcia et al. [44], Apuke et al. [45] \\
\hline $\begin{array}{l}\text { International Travel } \\
\text { Restrictions }\end{array}$ & Adekunle et al. [46], Anzai et al. [47], Tognotti [48], Wells et al. [49] \\
\hline Distance Learning & Rabi et al. [50], Stein [51], Ting et al. [52], Philips [53] \\
\hline $\begin{array}{l}\text { Economic Stimulus } \\
\text { Package }\end{array}$ & Ahmad et al. [54], Dorn et al. [55], Briefings [56] \\
\hline
\end{tabular}

contributions consisting of mass gathering cancellations, movements control order, limitation of international traveling, and distance learning seem essential. In the following sub-sections, these factors are discussed.

\subsection{Cancellation of Mass Gathering}

Public health authorities have different concerns about mass gatherings, such as the risk of the spread of infections by attendees across the world [22]. Prime Minister Muhyiddin restricted all collective unnecessary social functions such as religious ceremonies, sports, social and cultural activities during 18-31 March to deal with the outspread of COVID-19 [23, 24]. Moreover, to fight against the novel virus outspread, Latin American governments used usual prevention actions such as canceling mass events, classes of schools and universities, closing the borders, and limiting foreign travelers' entrance [25]. Furthermore, according to Aitsi-Selmi et al. [32], the population's mass gatherings as religious pilgrims and sports events can lead to considerable risks such as infection transmission, physical problems, and effects on the local as well as international health systems and services.

\subsection{Movement Control Order}

According to the Ministry of Health's recommendation, Malaysia's government concentrated on the execution of the $\mathrm{MCO}$, aimed at addressing the outspread of the COVID-19 virus. Accordingly, the state authorities could track the cases in all units over the determined period [31]. The order is primarily focusing on the isolation of the virus pandemic source. Prohibiting mass movements and gatherings across the country, such as sporting occasions, social and cultural functions, suspending all religious events in mosques such as the Friday prayers, prohibiting going out of the country along with restricting the entrance of nonMalaysian travelers into the country, closing all organizations and institutions except for the fundamental services as well as supermarkets, wet market, grocery stores and, those who sell daily necessary items, closing the nurseries, public and private schools consisting of boarding and international schools, secondary and pre-university educational institutes, together with the public and private universities and employment education, were all among the strategies to prevent or isolate the sources of virus spread [33]. Moreover, the general population has been asked to remain at homes and not to break regulations over the determined period toward preventing the virus from spread across Malaysia [34]. There has been a notable decline in traffic and industrial discharge because various industrial and commercial actions were rigorously not permitted during the first MCO phase [35]. During MCO, numerous activities, including operating business, is not permitted, except for necessary services [36].

\subsection{Social Media Sharing}

The modern media context is significantly dependent on social media as an important communication channel for news and information. One out of three individuals worldwide is involved in it, and two-thirds of internet users are utilizing it, along with its application as a critical instrument for public health [57]. In the current digital context worldwide, online platforms have been probably the most readily available sources of information associated with public health issues. These platforms, including Youtube, Instagram, and Twitter, can provide immediate access to vast amounts of content while contributing significantly as the sources of healthcare-associated information [58]. Mainstream platforms, including YouTube and Twitter, have documented the highest volume of interactions regarding the users' posts and comments associated with COVID-19 [41].

Social media is expected to contribute even more considerable in the distribution of information about COVID- 
19. As an instance, 255 million active users have been reported to be on Twitter in February 2014 when Ebola was prevalent [59], while the number came to 330 million in 2019 [60]. Social media provide forums for the collection of significant amounts of data that can be beneficial in making users and businesses aware of the current conditions so that they can make correct decisions at the proper time [42]. Moreover, social media can be considered an efficient marketing channel through which the integration of communications and marketing of travel services would be possible [61].

Tourists are growingly dependent on online comments instead of advertisements or guides to select experiences that are more compatible with their interests and expectations from the selected destinations [62]. The increase in social media application in tourism industries can be related to the users' direct recommendations provided by these media in relation to travel and the effective performance of mouth to mouth communications [63]. Thus, the tourists' destination priorities may change considerably through their awareness of the possible risks [64] over the outspread of the COVID-19 virus. As Chinazzi et al. [43] have stated, travel limitations because of COVID-19 outspread will impose moderate impacts, and the interventions aimed at reducing the virus transmission will have the highest advantages for the mitigation of the epidemics.

Based on the Malaysian Prime Minister's Office PMO [65], the government of Malaysia has taken the procedures determined by WHO since the start of the COVID-19 outspread, while the experts have also been advised to address the problem and assist in the prevention of the virus wide outbreak. Prime Minister Muhyiddin restricted all unnecessary social functions such as religious ceremonies, sports, social and cultural activities during 14-18 April to deal with the outspread of COVID-19 and react against the increasing trend of infection spread in Malaysia subject to the Movement Control Order across the country [24]. In addition to enforcing the Movement Control Order along with governmental financial assistance through specific economic packages, Senator Datuk Seri Dr. Zulkifli Mohamad Al-Bakri, Minister in Prime Minister's Department of Religious Affairs, asked Muslim communities to pray across the country. In addition to praying, charities seem necessary at the time of crisis, particularly given the public population's serious requirements to essential items for their survival. All charities and worshipping places have been invited to engage in charitable affairs [66], which seems necessary for the provision of physical as well as spiritual support. This has been predominantly observed in Waqf institutes, which have taken actions in advance in this regard [33].

\section{International Travel Restrictions}

Following the primary period of inactivity, different countries are recently imposing limitations on international travel aimed at the prevention of more importation of the COVID-19 virus into their borders. Nevertheless, considering that COVID-19 has become a worldwide pandemic at present, reaching almost all nations, investigating the effects of persistent travel limitations would seem reasonable [46]. Following restrictions in Wuhan, limitations on travel and control of the borders were carried out by different countries in the form of comprehensive travel bans, travel limitations and quarantines, allowing for restrictions of healthy people, entrance screening for every individual who enters the country, or some combinations of these strategies. Some governments have applied entrance limitations due to the emergence of the novel virus, while visa suspensions and quarantine measures have been considered for travelers [47]. The impacts of the travel ban, which were taken in Wuhan, and the global travel limitations which were imposed by different countries such as Malaysia were aimed at mitigating the outbreak in early February 2020. Travel limitations for disease control can be traced back to a long time ago and have always attracted policymakers as an instrument to calm the public concerns regarding foreign transmission [48]. The majority of modeling studies agreed that serious travel limitations could theoretically delay the outspread of the virus. Even though, according to estimations of one analysis, China's interior travel limitations decreased the speed of exporting SARS-CoV-2 infectious diseases and postponed the outbreak to unaffected cities. Simultaneously, according to another study, restrictions in Wuhan could delay the internal epidemic in China by $3-5$ days [49].

\subsection{Distance Learning}

Cancellation of the public school programs has been started in different countries to control the COVID-19 virus outspread and reduce the public health burden while releasing suggestions on school closure criteria [50]. The closure of educational institutes worldwide is supposed to result in fundamental (and probably unequal) interruptions in students' learning and problems in internal assessment procedures and cancellation of public evaluations for qualification or replacing them with lower-quality alternatives. The enrollments to distance learning programs through online instructional schedules and course accessibility are increasing [51]. According to Ting et al. [52], the ever-growing exploration of virtual online learning platforms aims at eliminating physical contacts. Nevertheless, since the MCO is extended another two weeks, teachers, 
parents, and students in Malaysia will adapt to distance learning with schools turning to online classes [53]. Several campuses are employing full-time "instructional designers" at present to facilitate faculty map out courses together with degree programs. Moreover, learning modules, online exercises, virtual laboratories, and measurements are also provided [67].

\subsection{Economic Stimulus Package}

The Malaysian government on 27 March 2020 publicized a stimulus package of 25 billion ringgit (US $\$ 2.3$ billion), it is the third since the beginning of the COVID-19 pandemic to delay the economic impacts of its month-long partial nationwide lockdown [68]. This package contains a 25 billion ringgit straight monetary injection by the government which, is intended to support families and business vendors impacted by the economic downturn caused by the coronavirus outbreak. The package could be vital for Small and Medium-Sized Enterprises (SMEs), making up 98 percent of Malaysia's economy. Support packages for businesses are designed to provide governments with the ability to keep community distance and stay home without worrying about the economic consequences and help keep the economy flooded by supporting the demand side of the economy.

\section{Methodology}

In this research, we used DEMATEL to find the causal relationships among factors impacting the prevention of the spread of the COVID-19 infection in Malaysia. Accordingly, Fuzzy Rule-Based techniques were applied to explore the critical significant influencing factors and expose the importance of determining factors based on the model inputs. The factors which this study aims to investigate on the prevention of infection are Social Media Sharing (SMS), Cancelation of Mass Gathering (CMG), Movement Control Order (MCO), International Travel Restrictions (ITR), Distance Learning (DL), Economic Stimulate Package (ESP). The data collection was performed by a questionnaire, as attached in Appendix A. For data analysis, we applied the DEMATEL technique to find the importance level of factors for preventing disease in Malaysia. The DEMATEL technique and data collection procedure will be described in the following sections.

\section{DEMATEL}

DEMATEL is widely used as a MCDM approach for many real-world decision analyses in recent years $[17,69,70]$. Compared to the other methods, the advantage of this technique is its ability to find the interdependencies among the factors in their impact from the decision-makers' perspectives. This MCDM approach can also find the relative importance of each factor in the net cause and net receiver groups and plot the network relationship map in the causal relationships, which can be better understood. The digraphs provided by DEMATEL show the direct relationships of sub-systems, representing a communication network. The steps of DEMATEL are shown in Fig. 1.

\subsection{Mamdani Fuzzy Rule-Based Systems}

Fuzzy logic is identified as a useful approach for handling the nature of uncertainty in human mistakes [71-73]. The fuzzy logic applications have been successfully investigated in several areas for handling complex problems directed to uncertainty [74-76]. The fuzzy system classifies complex decision-making difficulties into an easy hierarchical structure and then conducts evaluations by pair-wise comparisons. Fuzzy logic enables researchers to examine the input data imprecision and vague it comprehensively, and generate a more consistent model for calculating input-output relations [77].

Mamdani Fuzzy Rule-Based Systems (MFRBS) is the fuzzy model and a well-known soft computing approach proposed by Mamdani [78]. In a widespread sense, fuzzy rule-based methods are rule-based methods, where fuzzy sets and fuzzy logic are utilized as mechanisms for expressing various kinds of knowledge regarding the problem at hand and modeling the communications and existing relations among its variables [79, 80]. Each rule's output is a fuzzy set in this type of Fuzzy Inference System (FIS) (see Fig. 2). As Mamdani Fuzzy Inference System (FIS) has more intuitive and easier to understand rule bases, it is well-suited to expert system applications. For the inference process of the Mamdani fuzzy inference system [81, 82], two fuzzy rules (Rules 1 and 2) are presented, where $x_{i}$ and $y_{i}$ are input values for the fuzzy input set $A_{i}$ and $B_{i}, C_{i}$ is the fuzzy output set, and $\mu_{C_{j}}\left(z_{j}\right)$ is the membership degree of the output value $z_{j}$ (see Fig. 3). The defuzzied output $z_{c}$ is obtained using the centroid method as presented in Eq. (1).

$z_{c}=\frac{\sum_{j=1}^{k} \mu_{C_{j}}\left(z_{j}\right) \cdot z_{j}}{\sum_{j=1}^{k} \mu_{C_{j}}\left(z_{j}\right)}$ 
Step 1: Constructing the combined matrix of all respondents' feedback:

$$
A=\left[A_{i j}\right]_{n \times n}=\frac{1}{H} \sum_{k=1}^{H}\left[X_{i j}^{k}\right]_{n \times n}
$$

where the experts' preferences are provided in the matrices $X^{k}=\left[X_{i j}^{k}\right]_{n \times n}$ (for the $k$ th respondent).

Step 2: Constructing the normalized primary direct matrix:

$$
D X=\frac{A}{S}, \quad S=\max \left(\max \sum_{j=1}^{n} a_{i j}, \max \sum_{i=1}^{n} a_{i j}\right) .
$$

\section{Step 3: Constructing direct/indirect influence matrix:}

$$
\mathrm{T}=\mathrm{DX}(\mathrm{L}-\mathrm{DX})^{-1} \text {. }
$$

Step 4: Constructing two matrices $\mathrm{D}$ and $\mathrm{R}$ and finding net cause and net receiver factors through calculation $\mathrm{D}+\mathrm{R}$ and $\mathrm{D}-\mathrm{R}$.

$$
\begin{gathered}
T=\left[t_{i j}\right]_{n \times n} \quad i, j=1,2, \ldots n \\
D=\left(\sum_{j=1}^{n} t_{i j}\right)_{n \times 1} \quad i=1,2, \ldots n ; R=\left(\sum_{i=1}^{n} t_{i j}\right)_{1 \times n} \quad j=1,2, \ldots n
\end{gathered}
$$

Fig. 1 Overview of DEMATEL procedure

\subsection{Data Collection and Analysis}

The quantitative method was used in this study, along with questionnaires, to gather the required data. Data were gained by using the DEMATEL questionnaire survey (see Appendix A) of 22 experts applying purposeful sampling. Data collection was performed referring to the key knowledgeable people in health sciences and health care management, including public and private healthcare administrators at Malaysian universities. As for the educational level, $46.1 \%$ of the respondents have graduate degrees, followed by $31.2 \%$ of respondents as college graduates, and $22.7 \%$ of respondents as high-school graduates. More than three-quarters (77.6\%) of the respondents had more than eight years of healthcare experience. Furthermore, most of the respondents were female $(65 \%)$, and the rest were male (35\%). Despite the classical Structural Equation Modeling (SEM) method that needs an extensive research sample size to derive causal associations of factors, the DEMATEL, and fuzzy logic techniques can give acceptable research results from an almost small sample size through experts' perspectives [83]. Additionally, studying the literature about the defined sample sizes for DEMATEL determines that the maximum number of the studies employed a sample size between 10 and 30 [84-86]. Thus, a sample of 22 experts was enough to collect data in the present study for analyzing DEMATEL and fuzzy logic techniques.

\section{Data Analysis}

In this research, DEMATEL and Mamdani FIS are employed for data analysis. The results for these techniques are presented in this section.

The average matrix was identified in the first step of the DEMATEL technique. A pairwise comparison between factors established the measurement scale. Likert-scale at the range of 0 to 4 , indicating "no influence", "low influence", "medium influence", "strong influence", and "very strong influence", correspondingly was employed. In the next step, the overall average impact value was 


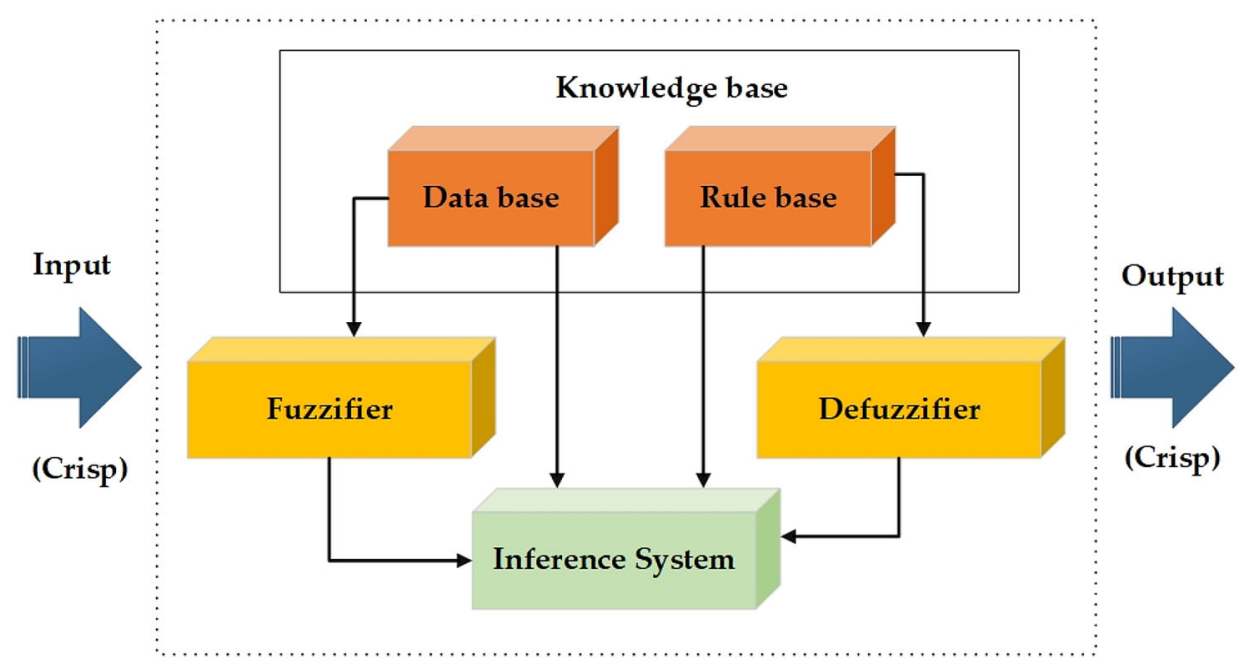

Fig. 2 Structure of fuzzy rule-based system

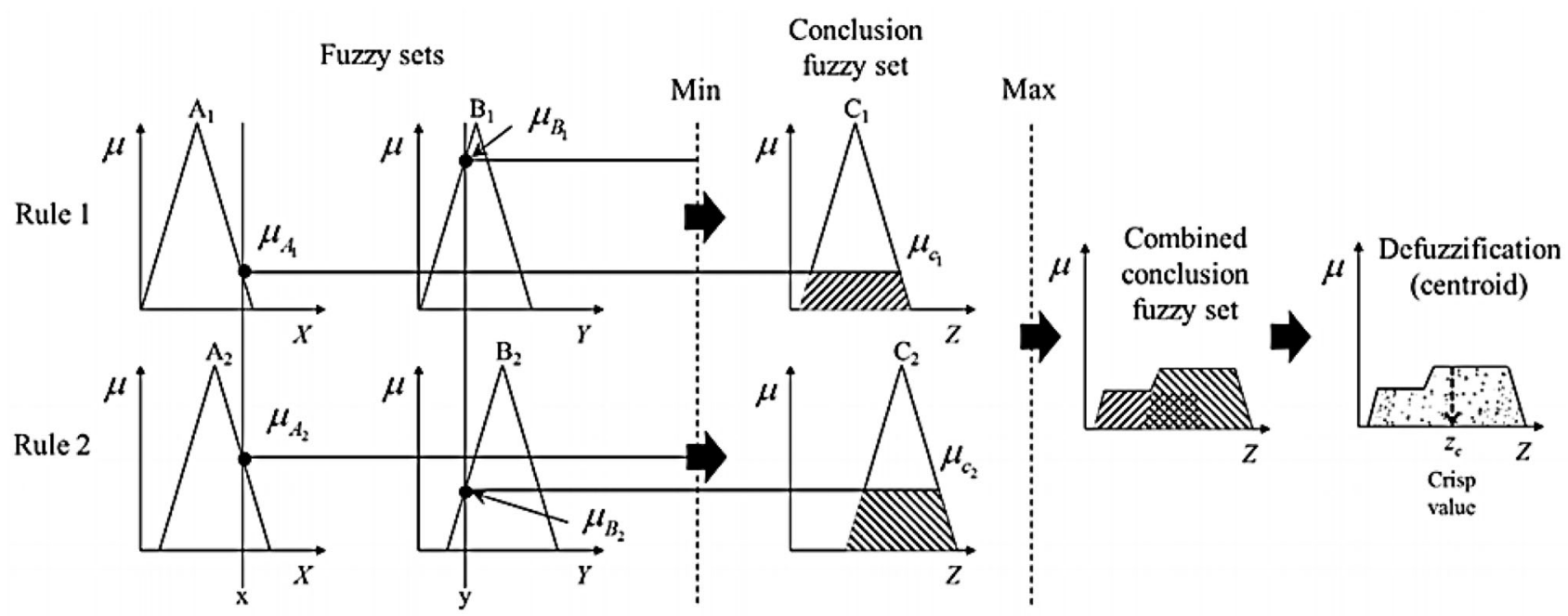

Rule 1. If ' $x$ ' is ' $A_{l}$ ' and ' $y$ ' is ' $B_{l}$ ' then ' $Z$ ' is ' $C_{l}$ '

Rule 2. If ' $x$ ' is ' $A_{2}$ ' and ' $y$ ' is ' $B_{2}$ ' then ' $Z$ ' is ' $C_{2}$ '

Fig. 3 Mamdani fuzzy inference system [81]

determined for all respondents, and then the normalized initial direct-relation matrix was calculated. The average of the twenty-two responses was employed to develop the average matrix (see Table 2). The normalized initial directrelation matrix was calculated through the normalization of the average matrix (see Table 3). The computation of the total relation matrix is was performed (see Table 4). It was possible to obtain the total relation matrix by the use of simple numerical calculations as represented in Step 3 in Fig. 1.

The net cause and net receiver factors were obtained from the total relation matrix. The results are presented in Table 5. Calculation of the value of each column (D) and row $(\mathrm{R})$ was eventually performed by the use of equations in Step 4, as indicated in Fig. 1, so that the prominence $(\mathrm{D}+\mathrm{R})$ and relation $(\mathrm{D}-\mathrm{R})$ could be obtained. According to the results, the significance of factors based on their weights is social media sharing, cancellation of mass gathering, movement control order, international travel restrictions, distance learning, and economic stimulate package. Moreover, according to findings, social media sharing, distance learning, and economic stimulate packages were affected by other preventive factors of COVID19. Finally, a threshold value was calculated, and the impact-relation map was obtained. It was necessary to eliminate some inappropriate impacts from the total relation matrix in order to illustrate the structural associations between the factors. The average value of the normalized 
Table 2 Average matrix

\begin{tabular}{lllllll}
\hline Factors & SMS & CMG & MCO & ITR & DL & ESP \\
\hline Social Media Sharing (SMS) & 0 & 2.45 & 2.95 & 2.6 & 2 & 2.2 \\
Cancelation of Mass Gathering (CMG) & 2.4 & 0 & 2.5 & 2.75 & 2.8 & 2.7 \\
Movement Control Order (MCO) & 2.45 & 3.05 & 0 & 2.95 & 3.25 & 3.15 \\
International Travel Restrictions (ITR) & 2.9 & 2.6 & 3.1 & 0 & 3.2 & 2.95 \\
Distance Learning (DL) & 2.45 & 1.9 & 2.25 & 2.45 & 0 & 2.8 \\
Economic Stimulate Package (ESP) & 2.65 & 2.35 & 1.65 & 1.7 & 1.85 & 0
\end{tabular}

Table 3 Normalized initial direct-relation matrix

\begin{tabular}{lllllll}
\hline Factors & SMS & CMG & MCO & ITR & DL & ESP \\
\hline Social Media Sharing (SMS) & 0 & 0.16 & 0.2 & 0.18 & 0.13 & 0.15 \\
Cancelation of Mass Gathering (CMG) & 0.16 & 0 & 0.17 & 0.19 & 0.19 & 0.18 \\
Movement Control Order (MCO) & 0.16 & 0.21 & 0 & 0.2 & 0.22 & 0.21 \\
International Travel Restrictions (ITR) & 0.2 & 0.18 & 0.21 & 0 & 0.22 & 0.2 \\
Distance Learning (DL) & 0.16 & 0.13 & 0.15 & 0.16 & 0 & 0.19 \\
Economic Stimulate Package (ESP) & 0.18 & 0.16 & 0.11 & 0.11 & 0.12 & 0 \\
\hline
\end{tabular}

Table 4 Total relation matrix

\begin{tabular}{lllllll}
\hline Factors & SMS & CMG & MCO & ITR & DL & ESP \\
\hline Social Media Sharing (SMS) & 0.89 & 1 & 1.03 & 1.01 & 1.02 & 1.07 \\
Cancelation of Mass Gathering (CMG) & 1.08 & 0.9 & 1.05 & 1.06 & 1.11 & 1.15 \\
Movement Control Order (MCO) & 1.18 & 1.17 & 1 & 1.17 & 1.23 & 1.28 \\
International Travel Restrictions (ITR) & 1.2 & 1.14 & 1.17 & 1 & 1.22 & 1.26 \\
Distance Learning (DL) & 0.99 & 0.94 & 0.96 & 0.97 & 0.86 & 1.06 \\
Economic Stimulate Package (ESP) & 0.9 & 0.86 & 0.83 & 0.83 & 0.87 & 0.79 \\
\hline
\end{tabular}

Table 5 Prominence and relation results obtained by DEMATEL

\begin{tabular}{lllll}
\hline Factors & $\mathrm{D}$ & $\mathrm{R}$ & $\mathrm{D}+\mathrm{R}$ & $\mathrm{D}-\mathrm{R}$ \\
\hline Social Media Sharing (SMS) & 6.02 & 6.23 & 12.25 & -0.21 \\
Cancelation of Mass Gathering (CMG) & 6.35 & 6.01 & 12.36 & 0.34 \\
Movement Control Order (MCO) & 7.03 & 6.04 & 13.07 & 0.99 \\
International Travel Restrictions (ITR) & 7.00 & 6.04 & 13.04 & 0.96 \\
Distance Learning (DL) & 5.78 & 6.3 & 12.08 & -0.52 \\
Economic Stimulate Package (ESP) & 5.07 & 6.61 & 11.68 & -1.55 \\
\hline
\end{tabular}

direct-relation matrix obtained equal to 0.07 . Thus, the importance of the factors are shown in Fig. 4. Visualization of the sophisticated causal associations was possible when the impact-relation map was drawn for the factors.

According to the impact-relation map matrix results (Table 6), movement control order affected all factors regarding preventing COVID-19 disease. Cancellation of the mass gathering was also affected by social media sharing, movement control order, international travel restrictions, distance learning and economic stimulate packages. In contrast, distance learning affected the economic stimulate package. Moreover, international travel restrictions affected the cancellation of mass gatherings, social media sharing, movement control order, distance learning and economic stimulate package. The findings also indicated that the economic stimulate package was significantly affected by movement control order, cancellation of mass gathering, social media sharing, international travel restrictions, and distance learning. 
The data analysis was further extended to the Mamdani fuzzy inference system. In a fuzzy rule-based system, we have applied different membership functions which are Gaussian and Triangular membership functions. Specifically, we considered Gaussian membership functions for the inputs and Triangular membership functions for the output (see Fig. 5). The linguistic variables for the inputs are: Low, Moderate, and High. We have considered five linguistic variables for the output: VLow, Low, Moderate, High, and VHigh. These linguistic variables are used to form the fuzzy rules in the FIS.

The data provided by the experts was collected and the fuzzy rules were extracted to be used in the inference process of the Mamdani fuzzy inference system. The extracted fuzzy rules are presented in Table 7. The fuzzy rules played an essential role in the prediction of Respond to the COVID-19 Outbreak through the input variables. It is seen that a total of 27 fuzzy rules were discovered from the data. The fuzzy rules are in the form of IF-THEN. These fuzzy rules are used in FIS to assess the level of Respond to the COVID-19 Outbreak according to the levels of Movement Control Order, International Travel Restrictions, and the Cancelation of Mass Gathering.

From Table 7, the first fuzzy rule is: IF [Cancelation of Mass Gathering $=\mathrm{High}]$ AND [Movement Control Order $=$ High $]$ AND [International Travel Restrictions $=$ High $]$ THEN [Respond to the COVID-19 Outbreak $=$ VHigh $]$. This indicates that for three input variables, "Cancelation of Mass Gathering", "Movement Control" Order and "International Travel Restrictions" if they are in the high level, the output (i.e., Respond to the COVID-19 Outbreak) is in very high level. In addition, from the third fuzzy rule, IF [Cancelation of Mass Gathering $=$ Low $]$ AND [Movement Control Order =

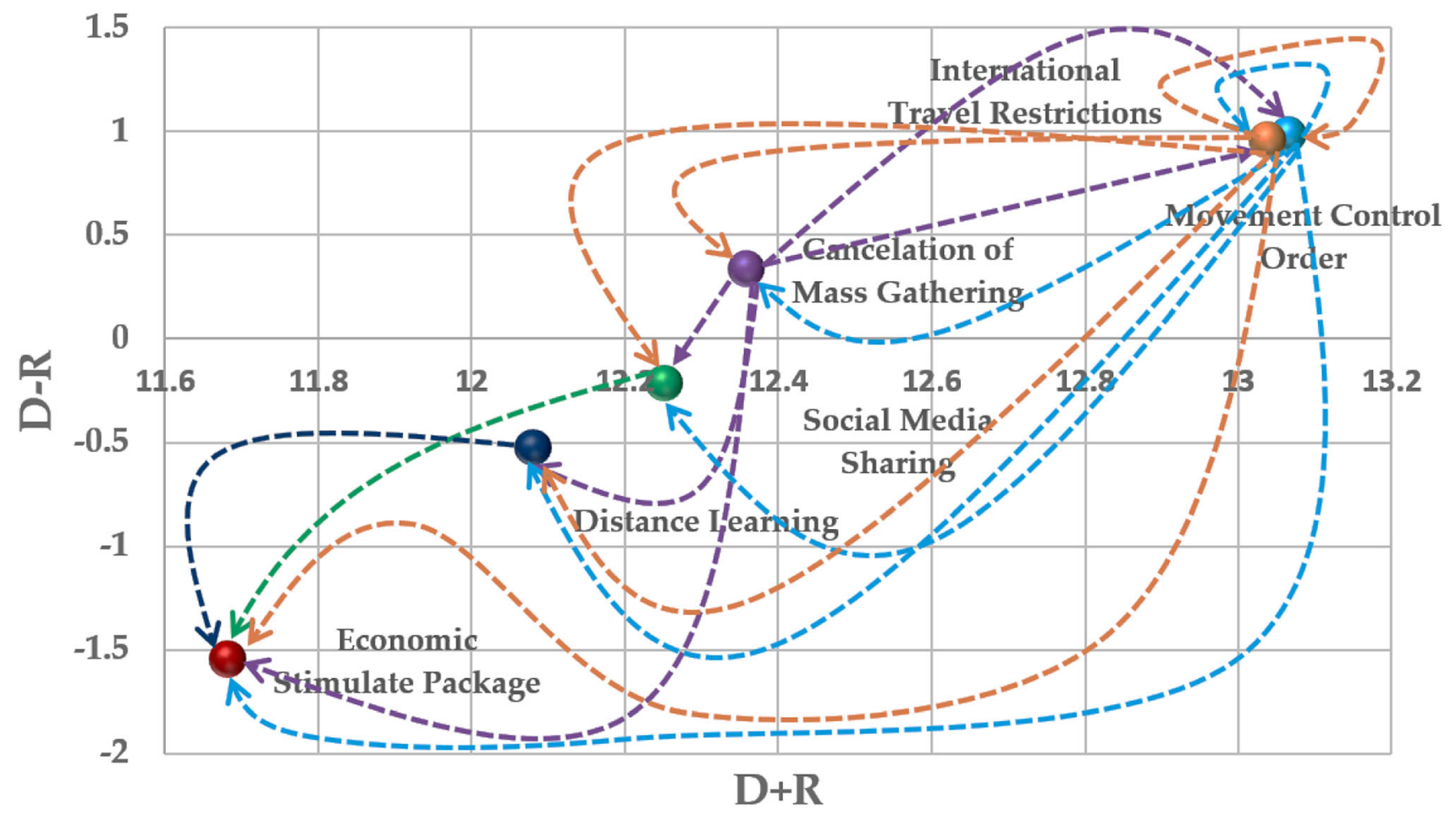

Fig. 4 Interactive influence between the six factors for responding COVID-19

Table 6 Impact-relation map matrix

\begin{tabular}{lllllll}
\hline Influence & SMS & CMG & MCO & ITR & DL & ESP \\
\hline Social Media Sharing & - & - & - & - & - & $\rightarrow$ \\
Cancelation of Mass Gathering & $\rightarrow$ & & $\rightarrow$ & $\rightarrow$ & $\rightarrow$ & $\rightarrow$ \\
Movement Control Order & $\rightarrow$ & $\rightarrow$ & - & $\rightarrow$ & $\rightarrow$ & $\rightarrow$ \\
International Travel Restrictions & $\rightarrow$ & $\rightarrow$ & - & - & $\rightarrow$ & $\rightarrow$ \\
Distance Learning & - & - & - & - & - & $\rightarrow$ \\
Economic Stimulate Package & - & - & - & - & - & - \\
\hline
\end{tabular}



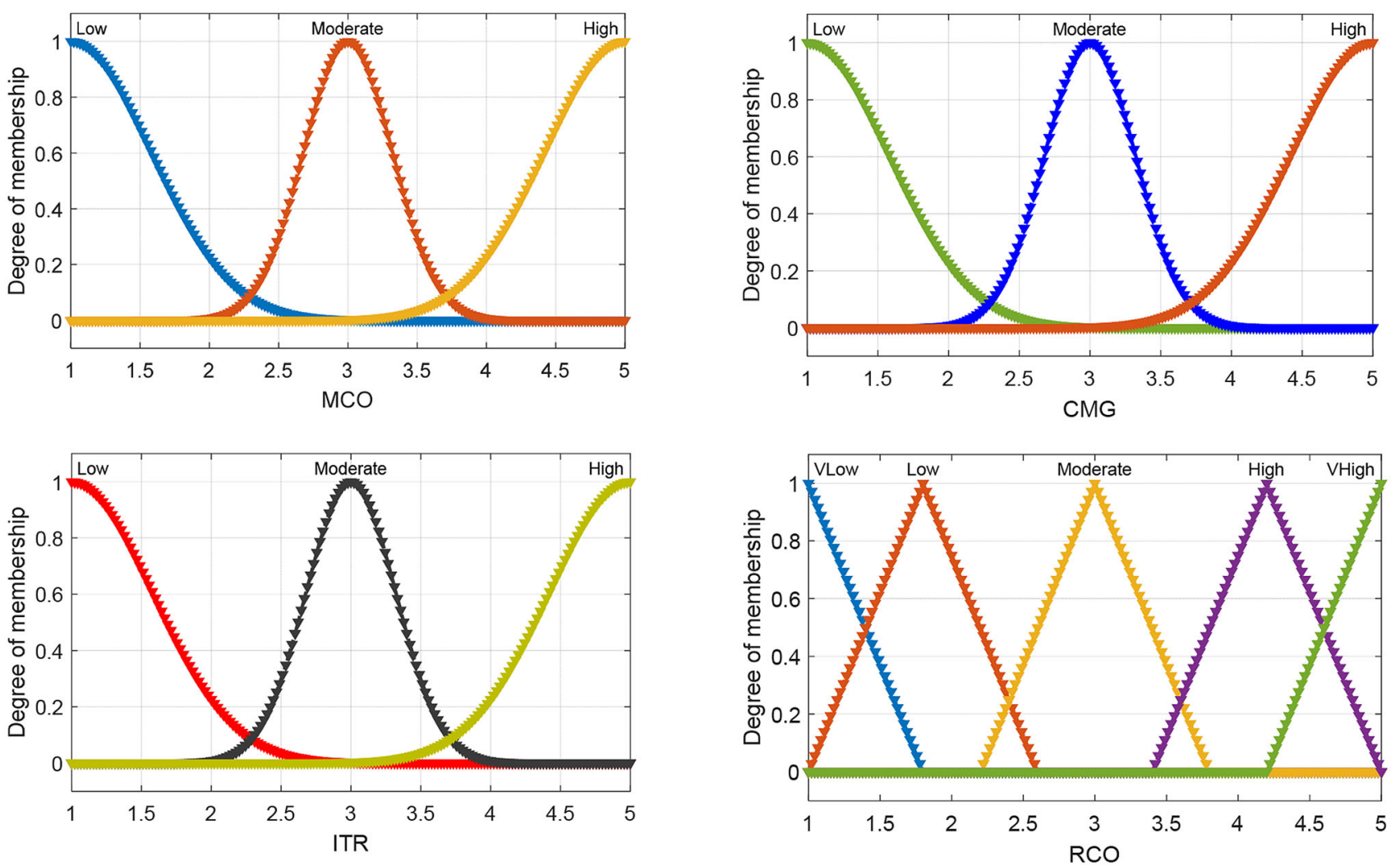

Fig. 5 Membership functions for system design

Table 7 Extracted fuzzy rules

\begin{tabular}{lllll}
\hline Rule \# & Movement Control Order & International Travel Restrictions & Cancelation of Mass Gathering & Respond to the COVID-19 Outbreak \\
\hline 1 & High & High & High & Very High \\
2 & High & High & Moderate & Very High \\
3 & High & High & Low & High \\
24 & Moderate & Low & Low & Low \\
25 & Moderate & Moderate & High & Moderate \\
26 & Moderate & Moderate & Moderate & Low \\
27 & Moderate & Moderate & Low & Low \\
\hline
\end{tabular}

High] AND [International Travel Restrictions $=$ High] THEN [Respond to the COVID-19 Outbreak = High]. This indicates that for Cancelation of Mass Gathering in low level and two input variables Movement Control Order and International Travel Restrictions in the high level, the output (i.e., Respond to the COVID-19 Outbreak) can be obtained in a high level. These results can be better shown in Figs. 6 and 7. In Fig. 6, the outputs are shown in 2D plots. In Fig. 7, 3D-plots of the surface view of the FIS are shown. From the results, it is clear that there is a positive relationship between the levels of Movement Control
Order, International Travel Restrictions and Cancelation of Mass Gathering, and Respond to the COVID-19 Outbreak.

\section{Discussion}

This study suggested several strategies for the government to help reduce the spread of the COVID-19 virus in Malaysian. The government's communication procedures toward enhancing the general population's awareness about the best ways to avoid the disease spread and additional 

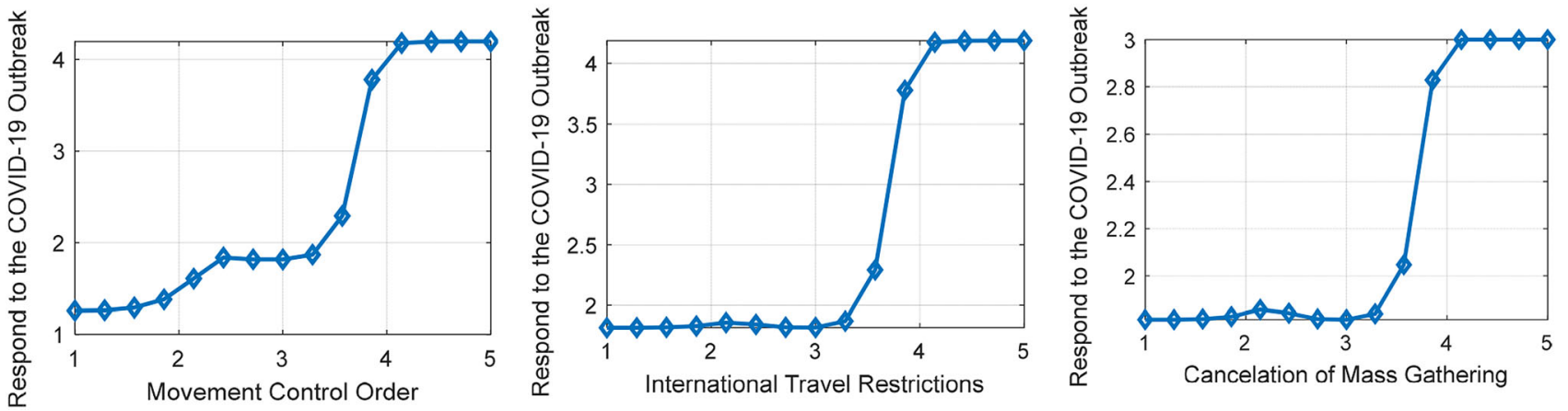

Fig. 6 The output for rule-based system

support for the management of economic challenges are of great importance. The proposed study applied the DEMATEL and fuzzy logic techniques to identify the most significant factors for the spread of COVID-19 prevention in the Malaysian context. As indicated, the preventive factors of spreading this virus in Malaysia can be considerably associated with social media sharing, cancellation of mass gathering, movement control order, international travel restrictions, distance learning, and economic stimulate package.

Based on the results of DEMATEL analysis, from the decision-makers' point of view, movement control order was regarded as the most influencing factor to decide regarding the prevention of COVID-19 spread in the Malaysian context. Regarding the most recent outspread of COVID-19, the Malaysian government's Movement Control Order was continued up to June 9, which was the fourth extension since March 18. Foreign and interstate travels were forbidden subject to the order, and citizens could leave their homes only for necessary shopping, leading to a nearly dead stop in the economy. No vaccines or efficient antiviral drugs are potentially accessible in the near future. Therefore, the only mitigating procedures at hand include voluntary as well as mandated quarantine, cancellation of mass gatherings, closing educational institutions or places of work that have been exposed by the infection, and isolating households, towns, or cities. According to Park et al. [87], although social distancing can ultimately prevent the outspread of the infection alone, its potential in flattening the epidemic curve would decrease the burden on the healthcare system. It can supply additional time to design and consider future plans.

As the DEMATEL method results indicated, international travel restriction was the second significant factor by the decision-makers to control and moderate the COVID19 expansion. Therefore, it was found that limitations on international travel by Malaysia's government affect the prevention of COVID-19 rapid spread significantly. This finding is consistent with the results of Adekunle et al. [46], who employed international flight data and disease transmission models for the prediction of national epidemic trajectories if the traveling restrictions were not imposed. According to the results of Costantino et al. [88], limitations of traveling affected the control of COVID-19 outspread in Australia considerably and prevented a broader and more extensive epidemic. Therefore, travel limitations are expected to have moderate impacts on the areas which have been already exposed by COVID-19. Simultaneously, interventions aimed at reducing transmission can result in the most significant benefits of epidemic mitigation.

Canceling or suspending the mass gatherings seems essential to mitigate the pandemic based on the results of DEMATEL and decision-makers' selection. While mass gatherings are regarded as the central determinants of the epidemiologic development of the disease outspread [11]. It was found in the present paper that canceling mass gatherings by the government of Malaysia has affected the prevention of COVID-19 rapid spread significantly. This finding agrees with the results of Anderson et al. [89], who indicated that the avoidance of people's large gatherings would decrease the number of super-spreading events. Nevertheless, if more extended contacts are needed for transmission, this action may reduce a small proportion of transmissions. Thus, broader-scale social distancing would probably be required, as was carried out by the Chinese government.

Social media sharing was found as a critical factor from the decision-makers' point of view toward COVID-19 prevention practices in Malaysia. Thus, in this paper, social media contribute significantly as an information source to enhance the awareness of population and travelers = and facilitate the prevention of COVID-19 rapid spread. Xiang, Gretzel [90] found that social media are actually a fundamental component of online tourism and can contribute considerably to travel planning through search engines. Social media platforms, including YouTube, and Twitter, make a tremendous volume of content available directly and reinforce rumors and doubtful information. Meantime, 


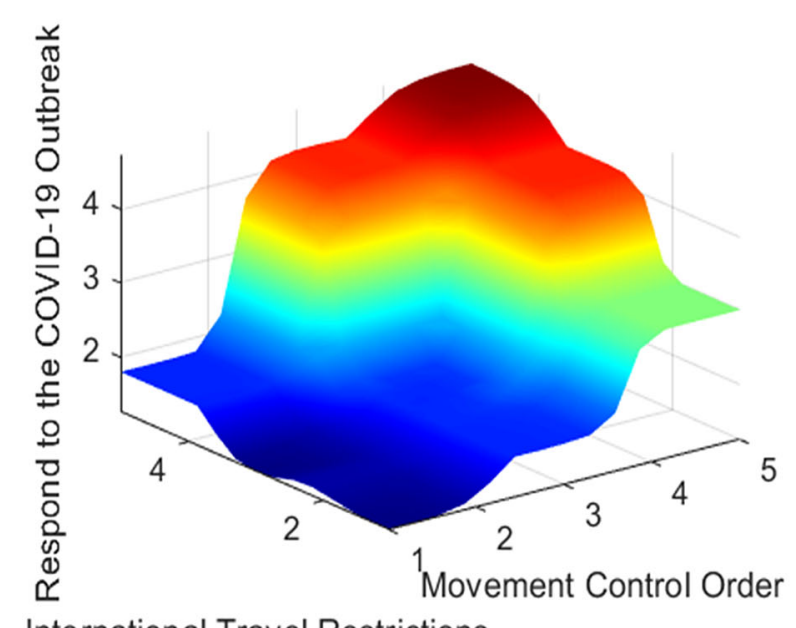

International Travel Restrictions

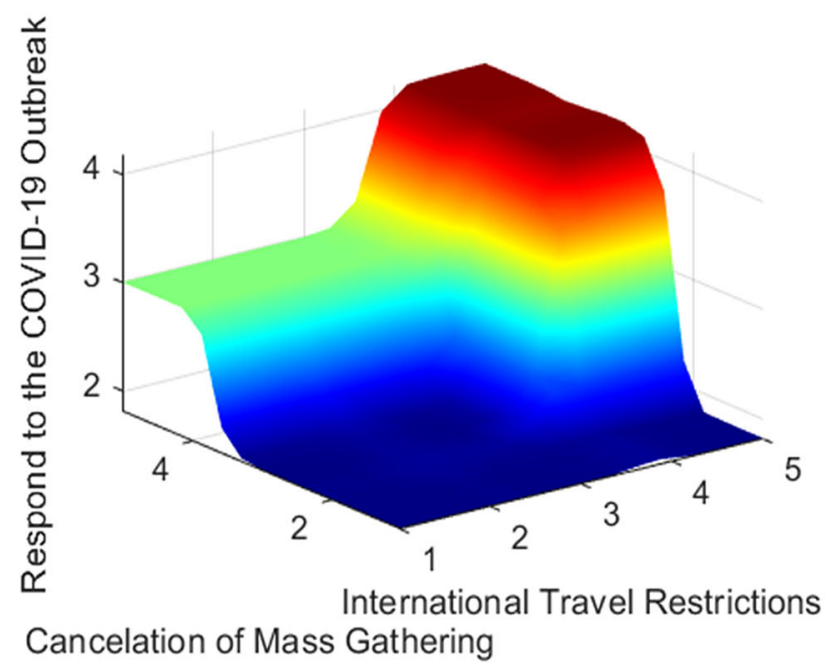

Fig. 7 The output for rule-based system 3D plots

Cinelli et al. [41] performed the analysis of mainstream platforms, including Twitter, Instagram, and YouTube, along with less regulated social media platforms consisting of Reddit and Gab. They indicated that topics were relatively the same, along with every social media platform. Comments ranged from comparing the current virus with other viruses, requesting God's blessing, to racist ideas, whereas the most incredible form of interactions was associated with the cancellation of flights. Furthermore, according to another finding in this paper, MCO by Malaysia's government affected the prevention of COVID19 rapid spread significantly. The Malaysian government considered prevention measures via Movement Control Order on the 18th of March 2020 by preventing and controlling infectious diseases. According to Ahmad [91], the Malaysian government enforced the same law in 2010 to prevent malaria.

Eventually, other results by the DEMATEL approach and decision-makers' perspectives showed that distance learning could significantly impact the prevention of COVID-19 rapid spread. The outspread of the virus profoundly affected the economic world, and the educational settings experience the effects. This finding is in line with the results of Abidah et al. [92], in which some regions closed their schools for the prevention of COVID-19 outspread. The ministry of education and culture has provided different facilitating strategies to keep on their education. In this regard, distance learning applications have been developed according to electronic portals and applications' availability. Conventional and routine learning styles emphasizing the teachers' and learners' interactions have changed to distance learning.

The fuzzy rule-based also are used in the fuzzy inference system to assess the level of response to the COVID19 outbreak. This method is utilized to reveal the hidden relationships between significant factors. Therefore, fuzzy rule-based results showed a positive relationship between the levels of a movement control order, international travel restrictions, and the cancelation of mass gathering in response to the COVID-19 outbreak.

\section{Conclusion and Recommendations}

The government of Malaysia has taken the procedures determined by WHO to reduce the outspread of the infection caused by COVID-19. At the same time, the experts in the country have also been requested to address the problem and assist in preventing the virus outbreak worldwide. According to the findings of the current study, factors including social media sharing, canceling mass gatherings, control of the movements, restrictions on international travels, and distance learning can significantly affect the prevention of COVID-19 increasingly rapid outspread. The COVID-19 outbreak has had considerable impacts on people's lives worldwide. Considering that no particular medicine has been found for it yet, prevention approaches seem essential. Thus, over this increasingly rapid emergence of the infection, learners and educators should be more flexible, while there is an evident need to investigate learning strategies that have not been wellstudied before. Limitation of physical contacts through engagement in social distancing can help in the reduction of the virus outspread. People's mass gatherings at religious ceremonies and sports will be associated with different health risks such as infection transmission, physical injuries, and effects on the local and international health systems and services. Therefore, the fights against the outspread of travel-associated infectious problems and other risks increased by globalization, arising from mass 
gatherings, should be considered a common commitment among all countries, sectors, and different contexts to get beneficial outcomes in risk reduction. Moreover, at the society level, the public population is supposed to keep away from crowded places and put off their unnecessary travels to destinations that can increase the continuous transmission challenge. In addition, as the virus has spread globally, reaching many areas of the world, investigating the effects of persistent travel limitations will be reasonable. Nevertheless, the limitations are expected to result in more favorable outcomes.

Before generalizing the results of the study, some of its limitations need to be presented. First of all, the principle of mass gathering, control of movements, restrictions on international travels, and distance learning effects on the control of disease spread has been illustrated in the present study focusing on the Malaysian context. The results of this study can be generalized to other countries. It is recommended for future researchers to consider a large sample population to achieve high result validity. For instance, with a large sample size, the clustering method can be performed for extracting fuzzy rules. Nevertheless, more studies are required to investigate other significant factors in preventing the COVID-19 rapid outbreak. Furthermore, for improving the accuracy and reliability of the achieved outcomes, integrated methods can be applied, i.e., using different MCDM tools along with DEMATEL methodology. Moreover, our method can be optimized with the help of new fuzzy methodologies developed in the previous research [93-95]. As this study focused on Malaysia as a scope of the research, future comparative studies might be conducted to extend the generalizability to entail other regions and compare their outcomes. Although the DEMATEL approach can present good results from a small sample size, future research might focus on deploying different statistical techniques with larger sample sizes that could include other decision-makers among organizations' staff and business sectors. The outcomes of their studies can then be compared with the results of this research.

\section{Appendix A: Study Questionnaire}

The COVID-19 pandemic has caused an unprecedented global crisis and led to many deaths, economic hardship and the disruption of everyday life. Malaysia's preparedness and planning began in December 2019, when they first heard from Chinese authorities that there were cases of acute respiratory illness. The present study investigates how Malaysia's government is dealing with the virus and its contribution to the mitigation of the risks associated with the virus. Therefore, we want to evaluate the factors impacting the prevention of the rapid outspread of the
COVID-19 virus. First, understanding these factors can aid us in moving in that direction. Second, it can help health administrators respond more effectively to the pandemic and ensure necessary care access.

Please specify the effect of the factor in the row on the factor in each column using one of the values ("no influence $=0 ", \quad$ "low influence $=1$ ", $\quad$ "medium influence $=2$ ", " "strong influence $=3$ ", and "very strong influence $=4$ "). Be assured that your responses to the questionnaire are for research purposes only and will not be used outside of this study. Finally, we appreciate your participation in this study. If you need the research results, we will be happy to provide professionals with the study outcome.

Thank you.

\section{Part I. Demographic Information \\ Gender: \\ Male $\square$ Female \\ Age: \\ 18-25 $\square 26-35 \square 36-45 \square 46-65 \square 66$ and above \\ Education level: \\ High School $\square$ College $\square$ Graduate School \\ Field of expertise: \\ Experience in your field: \\ $<3$ years $\square 3-5$ years $\square 6-8$ years $\square>8$ years \\ Part II. Comparison of the impact of the 6 factors (Please fill out the compared level of 6 factors in the following table)}

\begin{tabular}{lllllll}
\hline Factor & SMS & CMG & MCO & ITR & DL & ESP \\
\hline SMS & & & & & & \\
CMG & & & & & & \\
MCO & & & & & & \\
ITR & & & & & & \\
DL & & & & & & \\
ESP & & & & & &
\end{tabular}

Social Media Sharing (SMS); Cancelation of Mass Gathering (CMG); Movement Control Order (MCO); International Travel Restrictions (ITR); Distance Learning (DL); Economic Stimulate Package (ESP)

\section{References}

1. Cheng, S.-C., Chang, Y.-C., Chiang, Y.-L.F., Chien, Y.-C., Cheng, M., Yang, C.-H., Huang, C.-H., Hsu, Y.-N.: First case of Coronavirus Disease 2019 (COVID-19) pneumonia in Taiwan. J. Formos. Med. Assoc. 119, 747 (2020)

2. Nilashi, M., Samad, S., Yusuf, S.Y.M., Akbari, E.: Can complementary and alternative medicines be beneficial in the treatment of COVID-19 through improving immune system function? J. Infect. Public Health 13(6), 893 (2020) 
3. Al-Betar, M.A., Alyasseri, Z.A.A., Awadallah, M.A., Doush, I.A.: Coronavirus herd immunity optimizer (CHIO). Neural Comput. Appl. (2020). https://doi.org/10.1007/s00521-02005296-61-32

4. Kurniawan, R., Abdullah, S.N.H.S., Lestari, F., Nazri, M.Z.A., Mujahidin, A., Adnan, N.: Clustering and Correlation Methods for Predicting Coronavirus COVID-19 Risk Analysis in Pandemic Countries. In: 2020 8th International Conference on Cyber and IT Service Management (CITSM) 2020, pp. 1-5. IEEE

5. Ahmed, Q.A., Memish, Z.A.: The cancellation of mass gatherings (MGs)? Decision making in the time of COVID-19. Travel Med. Infect. Dis. 34, 101631 (2020)

6. Rupani, P., Nilashi, M., Abumalloh, R., Asadi, S., Samad, S., Wang, S.: Coronavirus pandemic (COVID-19) and its natural environmental impacts. Int. J. Environ. Sci. Technol. (2020). https://doi.org/10.1007/s13762-020-02910-x

7. Mat, N.F.C., Edinur, H.A., Razab, M.K.A.A., Safuan, S.J.J.: A single mass gathering resulted in massive transmission of COVID-19 infections in Malaysia with further international spread. J. Travel. Med. (2020). https://doi.org/10.1093/jtm/ taaa059

8. Nazri, A.S., Talib, K.A., Harun, Z., Sulaiman, A.N.J.: Humanities: Malaysia: state and society measures in safety and security against COVID-19. Soc. Sci. Hum. 6(1), 187-194s (2021)

9. Malaysia, M.O.H.: Covid-19 (latest updates). Retrieved from http://www.moh.gov.my/index.php/pages/view/2019-ncovwu han. Accessed 20 April 2020

10. See, K., Liew, S., Ng, D.C., Chew, E., Khoo, E., Sam, C., Sheena, D., Filzah, M.Z., Chin, S., Lee, P.: COVID-19: four paediatric cases in Malaysia. Int. J. Infect. Dis. 94, 125 (2020)

11. Azlan, A.A., Hamzah, M.R., Sern, T.J., Ayub, S.H., Mohamad, E.: Public knowledge, attitudes and practices towards COVID-19: a cross-sectional study in Malaysia. PLoS ONE 15(5), e0233668 (2020)

12. Malaysia, P.M.S.O.O.: Implementation of conditional MCO a correct move - PM. https://www.pmo.gov.my/2020/10/imple mentation-of-conditional-mco-a-correct-move-pm/ (2020).

13. Nadzir, M.S.M., Ooi, M.C.G., Alhasa, K.M., Bakar, M.A.A., Mohtar, A.A.A., Nor, M.F.F.M., Latif, M.T., AbdHamid, H.H., Ali, S.H.M., Ariff, N.M.J.A.: The impact of movement control order (MCO) during pandemic COVID-19 on local air quality in an urban area of Klang valley, Malaysia. Aerosol Air Qual. Res. 20(6), 1237-1248 (2020)

14. Sundarasen, S., Chinna, K., Kamaludin, K., Nurunnabi, M., Baloch, G.M., Khoshaim, H.B., Hossain, S.F.A., Sukayt, A.J.I.J.: Psychological impact of covid-19 and lockdown among university students in Malaysia: implications and policy recommendations. Public Health 17(17), 6206 (2020)

15. Chung, E., Subramaniam, G., Dass, L.C.J.A.: Online learning readiness among university students in Malaysia amidst COVID19. Asian J. Univ. Educ. 16(2), 46-58 (2020)

16. Kou, G., Lu, Y., Peng, Y., Shi, Y.J.I.J., Making, D.: Evaluation of classification algorithms using MCDM and rank correlation. Int. J. Inf. Technol. Decis. Mak. 11(01), 197-225 (2012)

17. Nilashi, M., Zakaria, R., Ibrahim, O., Majid, M.Z.A., Zin, R.M., Farahmand, M.: MCPCM: a DEMATEL-ANP-based multi-criteria decision-making approach to evaluate the critical success factors in construction projects. Arab. J. Sci. Eng. 40(2), 343-361 (2015)

18. Chiu, Y.-J., Chen, H.-C., Tzeng, G.-H., Shyu, J.Z.: Marketing strategy based on customer behaviour for the LCD-TV. Int. J. Manag. Decis. Mak. 7(2-3), 143-165 (2006)

19. Li, Y., Hu, Y., Zhang, X., Deng, Y., Mahadevan, S.: An evidential DEMATEL method to identify critical success factors in emergency management. Appl. Soft Comput. 22, 504-510 (2014)
20. Seyed-Hosseini, S.M., Safaei, N., Asgharpour, M.: Reprioritization of failures in a system failure mode and effects analysis by decision making trial and evaluation laboratory technique. Reliab. Eng. Syst. Saf. 91(8), 872-881 (2006)

21. Yu, D., Wang, W., Zhang, W., Zhang, S.: A bibliometric analysis of research on multiple criteria decision making. Curr. Sci. 114(4), 747-758 (2018)

22. Karami, M.: Sporting mass gatherings: public health preparedness and responsibility of health authorities. J. Res. Health Sci. 18, 3 (2018)

23. Tee, K.: Minister: Employers must pay salaries during COVID19 shutdown. Malay Mail (2020).

24. Crawford, J., Butler-Henderson, K., Rudolph, J., Malkawi, B., Glowatz, M., Burton, R., Magni, P.A., Lam, S.: COVID-19: 20 countries' higher education intra-period digital pedagogy responses. J. Appl. Learn. 3, 1 (2020)

25. Montanez, A.: Number of confirmed cases of novel coronavirus (COVID-19) in Latin America and the Caribbean as of March 31, 2020, by country (2020)

26. Ahmad, Z.A., Manan, K.A.J.T.J.: Media: knowledge, attitude on health practices of university students and staffs during the COVID-19 pandemic in Malaysia. J. Soc. Media. 4(2), 367-384 (2020)

27. Idris, Z.J.J.: Positioning Malaysia in the realm of global uncertainty: analysing its concern and struggles of Pakatan Harapan Government. J. Int. Stud. 16, 159-182 (2020)

28. Ahmed, Q.A., Memish, Z.A.J.T., Disease, I.: The cancellation of mass gatherings (MGs)? Decision making in the time of COVID19. Travel. Med. Infect. Technol. 34, 101631 (2020)

29. Escher Jr, A.R.J.C.: An ounce of prevention: coronavirus (COVID-19) and mass gatherings. Cureus 12(3), e7345 (2020)

30. Alshammari, S.M., Waleed, K., Algarni, S.M.: Preliminary evaluation of global mass gatherings suspension in Saudi Arabia during the COVID-19 pandemic

31. PMO: Enhanced Movement Control Order (EMCO) at Selangor Mansion and Malayan Mansion, KL (2019)

32. Aitsi-Selmi, A., Murray, V., Heymann, D., McCloskey, B., Azhar, E.I., Petersen, E., Zumla, A., Dar, O.: Reducing risks to health and wellbeing at mass gatherings: the role of the Sendai Framework for Disaster Risk Reduction. Int. J. Infect. Dis. 47, 101-104 (2016)

33. Sarif, S.M., Yahya, R.: Managing Crisis with "unprecedented situation deals with unprecedented measures": The Case Movement Control Order on Coronavirus Disease 19 (COVID-19) in Malaysia. (2020)

34. Yusof, A.: COVID-19: Malaysia to implement enhanced measures for second phase of movement control order (2020)

35. Heikal Ismail, M., Ghazi, T.I.M., Hamzah, M.H., Manaf, L.A., Tahir, R.M., Mohd Nasir, A., Ehsan Omar, A.J.S.: Impact of Movement Control Order (MCO) due to Coronavirus Disease (COVID-19) on food waste generation: a case study in Klang Valley, Malaysia. Sustainability 12(21), 8848 (2020)

36. Abdullah, S., Mansor, A.A., Napi, N.N.L.M., Mansor, W.N.W., Ahmed, A.N., Ismail, M., Ramly, Z.T.A.J.S.: Air quality status during 2020 Malaysia Movement Control Order (MCO) due to 2019 novel coronavirus (2019-nCoV) pandemic. Sci. Total Environ. 729, 139022 (2020)

37. Karim, W., Haque, A., Anis, Z., Ulfy, M.A.J.I.T.: The movement control order (mco) for covid-19 crisis and its impact on tourism and hospitality sector in Malaysia. Int. Tour. Hosp. J. 3(2), 1-7 (2020)

38. Khor, V., Arunasalam, A., Azli, S., Khairul-Asri, M.G., Fahmy, O.J.U.: Experience from Malaysia during the COVID-19 movement control order. Urology 141, 179-180 (2020) 
39. Tang, K.H.D.J.J.: Movement control as an effective measure against Covid-19 spread in Malaysia: an overview. J. Public Health. 13, 1-4 (2020)

40. Ash'aari, Z.H., Aris, A.Z., Ezani, E., Kamal, N.I.A., Jaafar, N., Jahaya, J.N., Manan, S.A., Saifuddin, M.F.U.J.A.: Spatiotemporal variations and contributing factors of air pollutant concentrations in Malaysia during movement control order due to pandemic COVID-19. Aerosol Air Qual. Res. 20(10), 2047-2061 (2020)

41. Cinelli, M., Quattrociocchi, W., Galeazzi, A., Valensise, C.M., Brugnoli, E., Schmidt, A.L., Zola, P., Zollo, F., Scala, A.: The covid-19 social media infodemic. arXiv preprint https://arxiv.org/ 2003.05004 (2020)

42. Ahani, A., Nilashi, M.: Coronavirus outbreak and its impacts on global economy: the role of social network sites. J. Soft Comput. Decis. Support Syst. 7(2), 19-22 (2020)

43. Chinazzi, M., Davis, J.T., Ajelli, M., Gioannini, C., Litvinova, M., Merle/r, S., Piontti, A.P., Mu, K., Rossi, L., Sun, K.: The effect of travel restrictions on the spread of the 2019 novel coronavirus (COVID-19) outbreak. Science 368, 395 (2020)

44. Cuello-Garcia, C., Pérez-Gaxiola, G., van Amelsvoort, L.J.J.: Social media can have an impact on how we manage and investigate the COVID-19 pandemic. J. Clin. Epidemiol. 127, 198-201 (2020)

45. Apuke, O.D., Omar, B.J.T.: Informatics: fake news and COVID19: modelling the predictors of fake news sharing among social media users. Telemat. Inf. 56, 101475 (2020)

46. Adekunle, A.I., Meehan, M., Alvarez, D.R., Trauer, J., McBryde, E.: Delaying the COVID-19 epidemic in Australia: Evaluating the effectiveness of international travel bans. medRxiv (2020)

47. Anzai, A., Kobayashi, T., Linton, N.M., Kinoshita, R., Hayashi, K., Suzuki, A., Yang, Y., Jung, S.-M., Miyama, T., Akhmetzhanov, A.R.: Assessing the impact of reduced travel on exportation dynamics of novel coronavirus infection (COVID-19). J. Clin. Med. 9(2), 601 (2020)

48. Tognotti, E.: Lessons from the history of quarantine, from plague to influenza A. Emerg. Infect. Dis. 19(2), 254 (2013)

49. Wells, C.R., Sah, P., Moghadas, S.M., Pandey, A., Shoukat, A., Wang, Y., Wang, Z., Meyers, L.A., Singer, B.H., Galvani, A.P.: Impact of international travel and border control measures on the global spread of the novel 2019 coronavirus outbreak. Proc. Natl. Acad. Sci. USA 117(13), 7504-7509 (2020)

50. Rabi, F.A., Al Zoubi, M.S., Kasasbeh, G.A., Salameh, D.M., AlNasser, A.D.: SARS-CoV-2 and Coronavirus Disease 2019: what we know so far. Pathogens 9(3), 231 (2020)

51. Stein, D.S.: Keeping the Promise of Distance Education: Ethical Challenges for Higher Education Administrators. In: Handbook of Research on Ethical Challenges in Higher Education Leadership and Administration. pp. 281-295. IGI Global (2020)

52. Ting, D.S.W., Carin, L., Dzau, V., Wong, T.Y.: Digital technology and COVID-19. Nat. Med. 26, 459 (2020)

53. Philips, S.: Coping with Covid-19: Distance Learning and the Digital Divide. (2020)

54. Ahmad, N.N., Hanafi, W.N.W., Abdullah, W.M.T.W., Daud, S., Toolib, S.N.J.G.B.: The effectiveness of additional PRIHATIN SME economic stimulus package (PRIHATIN SME+) in Malaysia post-COVID-19 outbreak: a conceptual paper. Glob. Business Manag. Res. 12, 4 (2020)

55. Dorn, F., Fuest, C., Neumeier, F.: After the Great Economic Collapse: Germany's Stimulus Package to Recover the Economy in Times of Covid-19. In: CESifo Forum 2020, vol. 02, pp. 38-46. München: ifo Institut-Leibniz-Institut für Wirtschaftsforschung an der

56. Briefings, O.A.J.E.E.: Work on US COVID-19 economic stimulus package starts. (oxan-es)

57. Singh, L., Bansal, S., Bode, L., Budak, C., Chi, G., Kawintiranon, K., Padden, C., Vanarsdall, R., Vraga, E., Wang, Y.: A first look at COVID-19 information and misinformation sharing on Twitter. arXiv preprint https://arxiv.org/2003.13907 (2020)

58. Khatri, P., Singh, S., Belani, N.K., Leng, Y.Y., Lohan, R., Wei, L.Y., Teo, W.Z.: YouTube as source of information on 2019 novel coronavirus outbreak: a cross sectional study of English and Mandarin content. Travel Med. Infect. Dis. 35, 101636 (2020)

59. Twitter: Twitter. Twitter reports first quarter 2014 results; April 29, 2014. https://s22.q4cdn.com/826641620/files/doc_financials/ 2014/q1/2014_Q1_Earnings_Release.pdf. (2014)

60. Twitter: Twitter. Twitter reports first quarter 2019 results; April 23, 2019. Avail-able from:fromhttps://s22.q4cdn.com/ 826641620/files/doc_financials/2019/q1/Q1-2019-EarningsRelease.pdf. (2019)

61. Zeng, B., Gerritsen, R.: What do we know about social media in tourism? A review. Tour. Manag. Perspect. 10, 27-36 (2014)

62. Litvin, S.W., Blose, J.E., Laird, S.T.: Tourists' use of restaurant webpages: Is the internet a critical marketing tool? J. Vacat. Mark. 11(2), 155-161 (2005)

63. Çollu, E.F., Summak, M.E.: Use of social media For public relations purposes in tourism. Selçuk Üniv. Sosyal Bilimler Meslek Yüksek Okulu Dergisi 18(1), 75-88 (2016)

64. Cottrell, S., van der Duim, R., Ankersmid, P., Kelder, L.: Measuring the sustainability of tourism in Manuel Antonio and Texel: a tourist perspective. J. Sustain. Tour. 12(5), 409-431 (2004). https://doi.org/10.1080/09669580408667247

65. PMO: Prime Minister's Office of Malaysia. https://www.pmo. gov.my/special-contents/2019-novel-coronavirus-2019-ncov/. (2019)

66. Zakariyyah, L., Mohd Noor, A., Mhd Sarif, S.: Accounting practices and charitable giving: integrating Maqasid al-Shariah framework for Tabung Masjid in Malaysia. Int. J. Appl. Bus. Econ. Res. 15(16), 495-514 (2017)

67. Carey, K.: "Everybody Ready for the Big Migration to Online College? Actually, No." The New York Times, March 13, 2020, sec. The Upshot. https://www.nytimes.com/2020/03/13/upshot/ coronavirus-online-college-classesunprepared.html. (2020)

68. Reuters March 27: Malaysia announces \$58-billion stimulus package to cushion impact of coronavirus. (2020).

69. Yadegaridehkordi, E., Hourmand, M., Nilashi, M., Shuib, L., Ahani, A., Ibrahim, O.: Influence of big data adoption on manufacturing companies' performance: an integrated DEMATELANFIS approach. Technol. Forecast. Soc. Chang. 137, 199-210 (2018)

70. Dalvi-Esfahani, M., Niknafs, A., Kuss, D.J., Nilashi, M., Afrough, S.: Social media addiction: applying the DEMATEL approach. Telemat. Inf. 43, 101250 (2019)

71. Zhang, H., Kou, G., Peng, Y.J.E.J.O.R.: Soft consensus cost models for group decision making and economic interpretations. Eur. J. Oper. Res. 277(3), 964-980 (2019)

72. Kerk, Y.W., Tay, K.M., Lim, C.P.: Monotone fuzzy rule interpolation for practical modelling of the zero-order TSK fuzzy inference system. IEEE Trans. Fuzzy Syst. 26, 3860 (2021)

73. Memon, I., Hasan, M.K., Shaikh, R.A., Nebhen, J., Bakar, K.A.A., Hossain, E., Tunio, M.H.: Energy-efficient fuzzy management system for internet of things connected vehicular ad hoc networks. Electronics 10(9), 1068 (2021)

74. Kou, G., Ergu, D., Lin, C., Chen, Y.J.T., Economy, E.D.O.: Pairwise comparison matrix in multiple criteria decision making. Technol. Econ. Develop. Econ. 22(5), 738-765 (2016)

75. Zeng, F., Guo, J., Long, C.J.J.G.S.: A hybrid model of fuzzy logic and grey relation analysis to evaluate tight gas formation quality comprehensively. J. Grey Syst. 27, 3 (2015)

76. De, S.K.: On degree of fuzziness and fuzzy decision making. Cybern. Syst. 51(5), 600-614 (2020) 
77. Pandey, D.C., Kushwaha, G.S., Kumar, S.J.S.A.S.: Mamdani fuzzy rule-based models for psychological research. Appl. Sci. 2(5), 1-10 (2020)

78. Mamdani, E.H.: Application of fuzzy algorithms for control of simple dynamic plant. Proc. Inst. Electr. Eng. 12, 1585-1588 (1974)

79. Yadegaridehkordi, E., Nilashi, M., Shuib, L., Asadi, S., Ibrahim, O.J.I.J., Making, D.: Development of a SaaS adoption decisionmaking model using a new hybrid MCDM approach. Int. J. Inf. Technol. Decis. Mak. 18(06), 1845-1874 (2019)

80. Abdullah, S.N.H.S., Zainal, N.F.A., Abdullah, S., Bakar, A.A., Omar, K.: Paddy abnormality vision recognition tool based on multi-layered mamdani fuzzy modeling. Appl. Eng. Agric. 30(2), 325-334 (2014)

81. Cho, H.-C., Lee, D.H., Ju, H., Park, H.-C., Kim, H.-Y., Kim, K.S.: Fire damage assessment of reinforced concrete structures using fuzzy theory. Appl. Sci. 7(5), 518 (2017)

82. Nilashi, M., Bagherifard, K., Ibrahim, O., Janahmadi, N., Barisami, M.: An application expert system for evaluating effective factors on trust in B2C websites. Engineering 3(11), 1063 (2011)

83. Hwang, B.-N., Huang, C.-Y., Wu, C.-H.: A TOE approach to establish a green supply chain adoption decision model in the semiconductor industry. Sustainability 8(2), 168 (2016)

84. Bavafa, A., Mahdiyar, A., Marsono, A.K.J.S.: Identifying and assessing the critical factors for effective implementation of safety programs in construction projects. Saf. Sci. 106, 47-56 (2018)

85. Hsu, C.-W., Kuo, T.-C., Chen, S.-H., Hu, A.H.J.J.: Using DEMATEL to develop a carbon management model of supplier selection in green supply chain management. J. Clean. Prod. 56, 164-172 (2013)

86. Yang, Y.-P.O., Shieh, H.-M., Tzeng, G.-H.J.I.S.: A VIKOR technique based on DEMATEL and ANP for information security risk control assessment. Inf. Sci. 232, 482-500 (2013)

87. Park, S.W., Sun, K., Viboud, C., Grenfell, B.T., Dushoff, J.: Potential roles of social distancing in mitigating the spread of coronavirus disease 2019 (COVID-19) in South Korea. medRxiv (2020)

88. Costantino, V., Heslop, D.J., MacIntyre, C.R.: The effectiveness of full and partial travel bans against COVID-19 spread in Australia for travellers from China. medRxiv (2020)

89. Anderson, R.M., Heesterbeek, H., Klinkenberg, D., Hollingsworth, T.D.: How will country-based mitigation measures influence the course of the COVID-19 epidemic? Lancet 395(10228), 931-934 (2020)

90. Xiang, Z., Gretzel, U.: Role of social media in online travel information search. Tour. Manag. 31(2), 179-188 (2010)

91. Ahmad, A.M.: How malaria is practically eradicated in Malaysia-a reminiscence. Asian J. Res. Infect. Dis. 3, 27-32 (2020)

92. Abidah, A., Hidaayatullaah, H.N., Simamora, R.M., Fehabutar, D., Mutakinati, L.: The impact of Covid-19 to Indonesian education and its relation to the philosophy of "Merdeka Belajar." Stud Philos. Sci. Educ. 1(1), 38-49 (2020)

93. Bhattacharya, K., De, S.K.: A robust two layer green supply chain modelling under performance based fuzzy game theoretic approach. Comput. Ind. Eng. 152, 107005 (2021)

94. De, S.K., Mahata, G.C.: Solution of an imperfect-quality EOQ model with backorder under fuzzy lock leadership game approach. Int. J. Intell. Syst. 36(1), 421-446 (2021)

95. De, S.K., Nayak, P.K., Khan, A., Bhattacharya, K., Smarandache, F.: Solution of an EPQ model for imperfect production process under game and neutrosophic fuzzy approach. Appl. Soft Comput. 93, 106397 (2020)

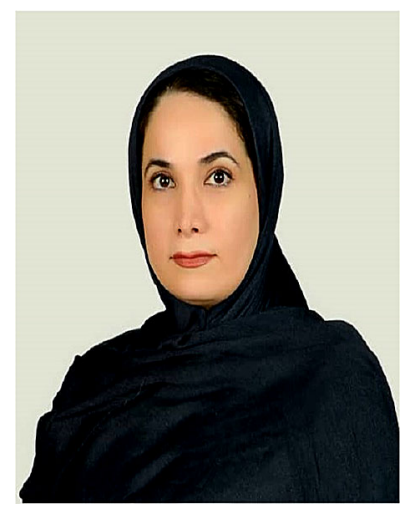

Shahla Asadi is currently a senior lecturer in the center of software technology and management, faculty of information science and technology, Universiti Kebangsaan Malaysia. She previously worked as a Postdoctoral-Fellow at the computer science and information technology faculty, University Putra Malaya. She received the M.S. and Ph.D. degrees in information technology management and information systems from Universiti Teknologi Malaysia in 2013 and 2017, respectively. She obtained the best postgraduate Ph.D. Student Award in the faculty of computing in October 2017. She has published several articles in internationally top-tier ranked journals and international conferences. Her research interests lie in Green Information Technology, Big data, Internet of Things, Individual and Organizational Behavior, and Information Systems Management. She is also an Active Member of the Association for Information Systems (AIS).

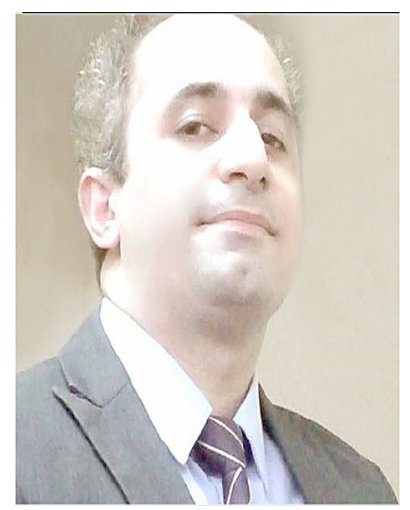

Mehrbakhsh Nilashi received his $\mathrm{Ph} . \mathrm{D}$. degree in Computer Science in the faculty of Computing, Universiti Teknologi Malaysia in 2014. His researches are mainly in the fields of Soft Computing, Machine Learning, Multi-criteria Decision Making, Information Retrieval, Recommender Systems with a special focus on Multi-Criteria Recommender Systems, Health Informatics, tourism management, and Decision Support Systems. His contributions have been published in prestigious peer-reviewed journals and international conferences.

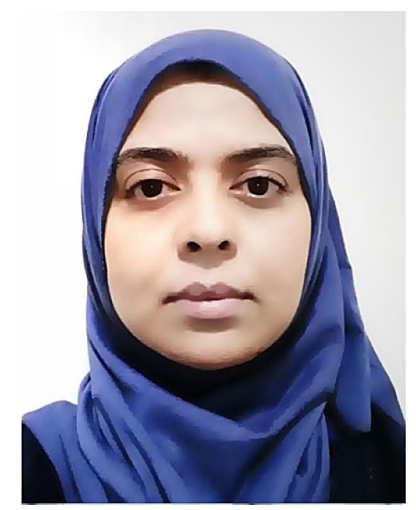

Rabab Ali Abumalloh currently works as a lecturer at Imam Abdulrahman Bin Faisal University, Faculty of Computing. She is enrolled in a Ph.D. program in the University of Technology, Malaysia, in the Computer Science program. Her research interests include recommender systems, tourism management, health informatics and Green IT/IS. 


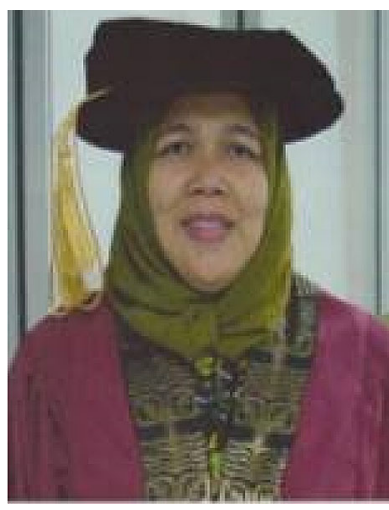

Sarminah Samad is an Associate Professor in CBA Research Centre, Department of Business Administration, Collage of Business and Administration, Princess Nourah Bint Abdulrahman University, Riyadh, Saudi Arabia. Her research expertise is focused on Technology Adoption, Social Informatics, and Business Research. Her contributions have been published in prestigious peer-reviewed journals and international conferences.

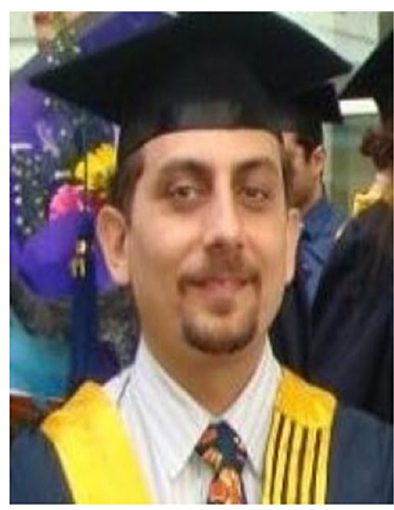

Ali Ahani received his Ph.D. degree in Information Systems at the Faculty of Computing, Universiti Teknologi Malaysia. His research interests include Technology Adoption, Business Informatics, Marketing Analytics, Health Informatics, Tourism Marketing and Recommender Systems. His contributions have been published in prestigious peer-reviewed journals and international conferences.

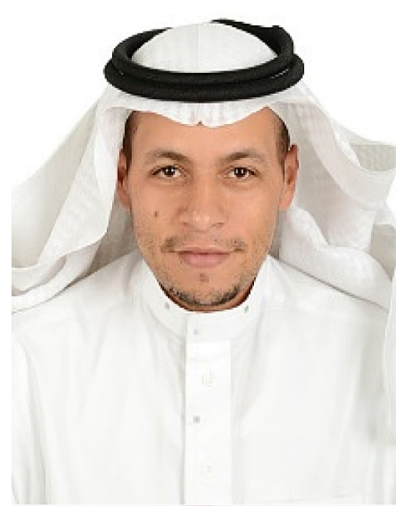

Fahad Ghabban was born in Saudi Arabia, Madinah in 1982. $\mathrm{He}$ received the B.S. degrees in computer science from the Taibah University, Saudi Arabia, in 2005 and the M.S. degrees in Information System from Wollongong University in Australia in 2010. Ph.D. degree in Information System from University Technology Malaysia University, Malaysia, in 2019. From 2014 to 2018 , he was a lecturer at college of computer science and engineering at Taibah

University. Since 2019, he has been an Assistant Professor with the information system department, Taibah University, College of computer science and engineering. He is the author of ten articles. His research interests include key performance indicators, information communication technology, knowledge sharing, software use in research, e-learning and e-governance. Dr. Fahad is Vice Dean of the College of Computer Science and Engineering for Graduate Studies and Scientific Research in Taibah University, college of computer science and engineering.

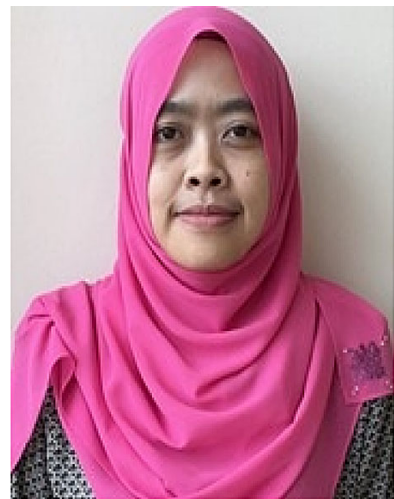

Salma Yasmin Mohd Yusuf is a lecturer and specialist of Family Medicine at Universiti Teknologi MARA, Department of Primary Care Medicine. Her research interests are in the fields of Family Medicine, Primary Care Medicine, Patient Education, and Health Care Management.

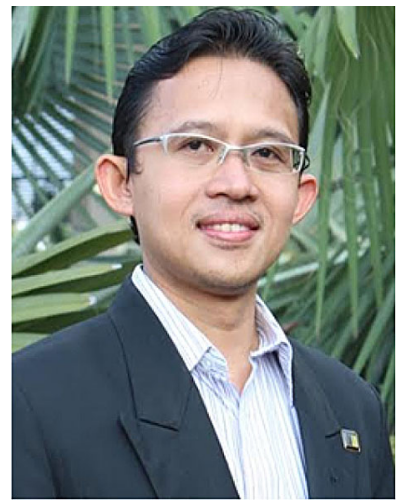

Eko Supriyanto is a full Professor at School of Biomedical Engineering \& Health Sciences, Universiti Teknologi Malaysia. $\mathrm{He}$ is a former director of IJNUTM Cardiovascular Engineering Centre. He obtained his $\mathrm{PhD}$ in Engineering from University of Federal Armed Forces Germany in Hamburg. He is an Adjunct Professor at Faculty of Computer Science and Automation, Ilmenau University of Technology, Germany. He is currently the General Chairman of ASEAN Network on Technology and Policy for COVID19 Risk Management. He is also the President of Indonesian Hospital Engineering Association. He published more than 350 indexed journal and proceeding papers, registered more than 50 patents and copyrights as well as obtained more than 35 international research awards. His research interests are applications of I.R 4.0 Technologies in Health, Management, and Energy. 